\title{
Estimation of Herd Incidence of Infection with Bovine Virus Diarhoea Virus (BVDV) in Herds Previously without Animals Persistently Infected with BVDV
}

\author{
By H. Houe and V. Palfi
}

Department of Clinical Studies, Division of Large Animal Medicine, Royal Veterinary and Agricultural University, Frederiksberg, and The National Veterinary Laboratory, Copenhagen, Denmark.

\begin{abstract}
Houe, $H$. and V. Palfi: Estimation of herd incidence of infection with bovine virus diarrhoea virus (BVDV) in herds previously without animals persistently infected with BVDV. Acta vet. scand. 1993, 34, 133-137. - On a previous occasion, all animals in 9 herds had been bled for bovine virus diarrhoea virus (BVDV) and antibodies. No animals persistently infected (PI) with BVDV were detected. Three years later 10 animals in each herd were tested again. By this time 60 out of 90 previously seronegative animals had seroconverted. Seroconversions had occurred in 8 of the 9 herds corresponding to a incidence risk of herd infection of 0.52 per year. The incidence risk of seroconversions in individual animals was 0.31 . Examination of young stock for antibodies and determination of antibody titer in bulk milk were good indicators for ongoing infections in the herds.

The number of herd infections seemed to be higher than could be explained from purchase of PI animals.
\end{abstract}

pestivirus; cattle; Denmark.

\section{Introduction}

Bovine virus diarrhoea virus (BVDV) is a pathogen occurring worldwide. Postnatal infection with BVDV is most often subclinical and followed by production of antibodies few weeks later (Brownlie 1990). During this acute infection pregnant animals will transmit the virus to their foetus. Depending on the gestational age the foetus may acquire various damages including foetal death, abortion, growth retardation and congenital defects (Van Oirschot 1983). Specifically, infection during the first trimester of pregnancy may cause immunotolerance against BVDV and the calf will be persistently infected (PI) for the rest of its life. PI calves may later succumb to fatal mucosal disease (Brownlie et al. 1984). Since acute infection is most often subclinical, the time and means of introduction of the infection are often unknown. Although direct introduction of a PI animal sometimes has been proved to be the source of infection (Roeder et al. 1986), the chain of events on other occasions is less clear (Meyling et al. 1990).

The purpose of this study is to estimate the herd incidence of infection with BVDV in herds that had previously been without PI animals. Further, the theoretical risk of having the infection introduced by purchase of a PI animal was calculated in each herd. 


\section{Materials and methods \\ Selection of herds}

Nineteen herds (Nos. 1-19) in which all animals had been bled for virological and serological examination for BVDV infection in November 1988 were chosen for the study. Ten herds (Nos. 1-10) contained PI animals whereas 9 herds (Nos. 11-19) contained no PI animals (Houe \& Meyling 1991).

\section{Blood testing}

In the 9 herds containing no PI animals in November 1988 blood samples were obtained from 10 previously seronegative animals in each herd. These samples were taken in October 1991, i.e. approximately 3 years after the first samples. The blood samples were examined for BVDV antibodies. Further, 5 animals aged $1 / 2-1 \frac{1}{2}$ year were bled and examined for BVDV antibodies.

The farmer and the local veterinarian were asked whether there had been signs of infection. If viraemic animals had been detected more animals of the same age were tested for virus. This was also done if any clinical signs of BVDV infection occurred within 6 months after the follow up sampling.

The blood samples were analysed for BVDV antibody by an indirect ELISA (Qvist submitted). Briefly, microtiter plates were coated with the gp (glycoprotein) $48.000 \mathrm{Ag}$ of NADL BVDV strain. Samples were tested at a dilution of 1:25. As a detector system peroxidase labelled rabbit anti-bovine immunoglobulins and OPD substrate were used. Virological examination was performed by an indirect immunoperoxidase technique (Meyling 1984).

\section{Examination of bulk milk}

From each of the 9 herds a bulk milk sample was tested for BVDV antibody titer using an indirect ELISA: After removal of the milk fat by centrifugation, the undiluted skimmed milk was examined for antibodies in the same manner as serum.

In order to minimize the effect of day to day variability bulk milk titer was calculated relative to a reference positive and negative milk sample (tested by virus neutralisation test). The specific absorbance per dilution step for the positive reference was calculated as the difference between absorbance values of the positive and negative reference samples divided by the two-fold dilution step. Using this parameter the absorbance for each test sample was recalculated to a titer.

In herds with few antibody positive animals despite a high bulk milk titer antibody negative animals were retested 6 months later.

\section{Calculations}

The Incidence risk of herd infection in the 3 years period was calculated as:

Incidence risk $=$ Number of herds with seroconversions/number tested

When calculating the incidence risk of herd infection the herd was rated as infected if at least 1 of the previously antibody negative animals had seroconverted.

For individual animals the incidence risk was calculated as:

Incidence risk $=$ Number of cattle with seroconversions/number tested

The incidence risk for a new time period y was calculated from the incidence risk in period $\mathrm{x}$ as (Martin et al. 1987):

Incidence risk in $\mathrm{y}=1$ - $(1 \text {-risk in } \mathrm{x})^{\mathrm{y} / \mathrm{x}}$

New purchases

The number of new introductions of animals 
Table 1. Antibody carriers among previously seronegative animals and young stock and antibody titers in bulk milk in 9 herds which contained no PI animals 3 years previously.

\begin{tabular}{|c|c|c|c|c|c|}
\hline \multirow[b]{2}{*}{ Herd Number } & \multicolumn{2}{|c|}{ Number of antibody positive animals } & \multirow{2}{*}{$\begin{array}{l}\text { Antibody } \\
\text { titer in } \\
\text { bulk milk }\end{array}$} & \multirow{2}{*}{$\begin{array}{c}\text { New intro- } \\
\text { ductions } \\
1988-1991\end{array}$} & \multirow{2}{*}{$\begin{array}{c}\text { Risk (P) } \\
\text { of buying } \\
\text { a PI animal }\end{array}$} \\
\hline & $\begin{array}{l}\text { Among } 10 \text { previously } \\
\text { seronegative animals }\end{array}$ & $\begin{array}{l}\text { Among } 5 \text { animals } \\
\text { aged } 1 / 2-1 \frac{1}{2} \text { years }\end{array}$ & & & \\
\hline 11 & 0 & 0 & 1 & 1 & 0.02 \\
\hline 12 & 10 & $12 *$ & 16 & 3 & 0.06 \\
\hline 13 & 6 & 0 & 64 & 0 & 0 \\
\hline 14 & 2 & 0 & 2 & 0 & 0 \\
\hline 15 & 10 & 2 & 64 & 81 & 0.81 \\
\hline 16 & 10 & 4 & 16 & 5 & 0.10 \\
\hline 17 & 10 & 3 & 32 & 2 & 0.04 \\
\hline 18 & 2 & 0 & 2 & 1 & 0.02 \\
\hline 19 & 10 & 5 & 64 & 11 & 0.20 \\
\hline
\end{tabular}

$P=1-0.98 n$

*Due to recent occurrence of mucosal disease in 2 calves in this age group, 15 calves aged 6-14 months were tested in this herd. The 3 antibody negative animals were viraemic.

In Herd 16 one antibody negative animal was found. This calf was persistently infected.

In Herd 13, three of the antibody negative cows and 1 of the antibody negative calves were antibody positive by testing 6 months later.

In Herds 15 and 17, all 5 young animals were tested 6 months later. By this time they were all antibody positive.

from 1985 until November 1988 was obtained for all 19 herds. The number of new introductions from November 1988 until October 1991 was obtained for herds previously without PI animals.

The theoretical risk of introducing the infection by new introduction of a PI animal was calculated as:

$\mathrm{P}=1$ - (the probability of buying a non-PI ${\text { animal })^{\mathrm{n}}}$

where $\mathrm{n}$ is the number of new introductions. Assuming a prevalence of PI animals of 2 per cent the equation is:

$P=1-0.98^{n}$

\section{Results}

Incidence risk

The number of antibody carriers among 10 previously antibody negative animals and among younger stock is seen in Table 1 . In the 3 year study period seroconversions had occurred in 8 of the 9 herds with 2-10 animals seroconverting in each herd. The risk incidence rate of herd infection can be calculated as:

Incidence risk $_{3 \text { years }}=8 / 9=0.89$ and

Iincidence risk $_{1 \text { year }}=1-(1-0.89)^{1 / 3}=0.52$

Among all 90 animals retested 60 had seroconverted:

Incidence risk $_{3 \text { years }}=60 / 90=0.67$ and Incidence risk $_{1 \text { year }}=1-(1-0.67)^{1 / 3}=0.31$

In 3 herds the bulk milk titer was low (Herds 11, 14 and 18). In Herd 11 no seroconversions and in Herds 14 and 18 two seroconversions had occurred during the 3 year period (Table 
1). In these 3 herds there were no antibody carriers among the young animals tested.

The remaining 6 herds all had high antibody titer in bulk milk. Viraemic animals were detected in 3 of these herds (Nos. 12, 16 and 19) after there had been signs of BVDV infection. In these herds all animals that were tested were antibody positive, except for viraemic animals (Table 1 ).

In 3 herds (Nos. 13, 15 and 17) fewer antibody carriers were found despite a high bulk milk titer. Therefore, a few follow up tests were made. In Herd 13, three of the antibody negative cows and 1 of the antibody negative calves were antibody positive when tested 6 months later. In Herds 15 and 17 all 5 young stock were tested 6 months later. By this time they were all antibody positive.

\section{New introductions}

In herds with PI animals there had been new introductions in all 10 herds during the period from 1985 until herd blood test in November 1988 whereas in herds without PI animals there had been new introductions in 6 of the 9 herds.

Table 1 shows the number of new introductions in the 9 herds without PI animals in the November 1988 test from this time until the follow up test in 1991. Further, the theoretical risk that the infection was introduced by purchase of a PI animal is shown. In only 2 herds this risk was higher than 10 per cent.

\section{Discussion}

This cohort study estimates the incidence of infection with BVDV. The total individual risk of infection of 0.31 compares well with the 0.34 calculated in a cross-sectional study from the age distribution of antibody carriers (Houe \& Meyling 1991).

The antibody titer in bulk milk seems to be a good indicator of active infection in the herds.
In all 6 herds with high antibody titer in bulk milk there was an active spread of infection. In Sweden, analysis of bulk milk samples is used routinely in the diagnosis of BVDV infections in dairy herds (Niskanen et al. 1991). It has been shown that serological examination of few animals among young stock can be used to reveal presence of PI animals (Houe 1992). PI animals were found in 3 herds. In these herds, all animals among the tested young stock were antibody positive except for PI animals.

The risk rate of herd infection was calculated as 0.52 per year. New introduction of animals seems an important cause of reintroduction of the infection, although from the number of new introductions it seems unlikely that all reinfections are caused by purchased PI animals. Some of the reinfections might be caused by purchase of acutely infected animals (Brownlie 1985) or by contact with other cattle on pasture. In Herd 13 there had been no new introductions since January 1987. But, in this herd, the animals on pasture were only separated from animals in the neighbour herd by a wire. So, in all herds the reinfection can be explained by either purchased animals or by contact with infected animals on pasture. Still, there might be other means of transmission of infection. Transmission by infected semen has been demonstrated (Meyling \& Jensen 1988). Indirect transmission by infected clothes or equipment used in caring for cattle as well as needles and surgical instruments have been considered as potential carriers of virus (Bolin 1990). Finally, the infection might originate from within the herd. It remains to be clarified whether antibody positive animals can, on rare occasions, excrete the virus. On the other hand there seems to be very little evidence for BVDV latency (Brownlie 1990). In endemic areas new herd infections seem to be very frequent unless strict precautions are 
taken. Very little is known about the precautions necessary in order to avoid introduction of infection. Studies in Denmark are in progress to investigate the possibility of preventing further spread of infection after removal of PI animals.

\section{Acknowledgement}

This study was made with support from the Danish Agricultural and Veterinary Research Council.

\section{References}

Bolin SR: Control of bovine virus diarrhoea virus. Rev. sci. tech. Off. int. Epiz. 1990, 9, 163-171.

Brownlie J: Clinical aspects of the bovine virus diarrhoea/mucosal disease complex in cattle. In Practice 1985, 7, 195-202.

Brownlie J: The pathogenesis of bovine virus diarrhoea virus infections. Rev. sci. tech. Off. int. Epiz. 1990, 9, 43-59.

Brownlie J, Clarke M C, Howard CJ: Experimental production of fatal mucosal disease in cattle. Vet. Rec. 1984, 114, 535-536.

Houe H: Serological analysis of a small herd sample to predict presence or absence of animals persistently infected with bovine virus diarrhoea virus (BVDV) in dairy herds. Res. Vet. Sci. 1992, 53, 320-323.

Houe H, Meyling A: Prevalence of bovine virus diarrhoea (BVD) in 19 Danish dairy herds and estimation of incidence of infection in early pregnancy. Prev. Vet. Med. 1991, 11, 9-16.

Martin S W, Meek A H, Willeberg P: Veterinary Epidemiology. Principles and Methods. Iowa State University Press, Ames, Iowa 1987, 343 pp.

Meyling A: Detection of BVD virus in viraemic cattle by an indirect immunoperoxidase technique. In: (McNulty MS, MacFerran JB (eds.)): Recent advances in virus diagnosis. Martinus Nijhoff Publishers, Boston 1984, 37-46.

Meyling A, Houe H, Jensen AM: Epidemiology of bovine virus diarrhoea virus. Rev. sci. tech. Off. int. Epiz. 1990, 9, 75-93.
Meyling A \& Jensen, AM: Transmission of Bovine Virus Diarrhoea Virus (BVDV) by Artificial Insemination (AI) with Semen from a Persistentlyinfected Bull. Vet. Microbiol. 1988, 17, 97-105.

Niskanen R, Alenius S, Larsson B, Jacobsson, S.-O.: Determination of level of antibodies to bovine virus diarrhoea virus (BVDV) in bulk tank milk as a tool in the diagnosis and prophylaxis of BVDV infections in dairy herds. Arch. Virol. 1991, Suppl. 3, 245-251.

Qvist P: An enzyme-linked immunosorbent assay for the detection of serum antibodies to bovine virus diarrhoea virus. Acta vet. scand. Submitted.

Roeder PL, Jeffrey M, Cranwell MP: Pestivirus fetopathogenicity in cattle: Changing sequelae with fetal maturation. Vet. Rec. 1986, 118, 44-48.

Van Oirschot $J$ T: Congenital infections with nonarbo togaviruses. Vet. Microbiol. 1983, 8, 321361.

\section{Sammendrag}

Estimering af besatningsincidensen af infektion med bovin virusdiarré virus (BVDV) $i$ besatninger, der tidligere er fundet uden persistent inficerede dyr.

I 9 besætninger var alle dyr tidligere blodprøvet for virologisk og serologisk unders $\varnothing$ gelse. I besætningerne var der ikke fundet persistent inficerede dyr. Tre år senere blev $10 \mathrm{dyr}$ i hver besætning prøvet igen. Nu havde 60 ud af 90 tidligere antistofnegative dyr serokonverteret. Der var indtrådt serokonverteringer i 8 af de 9 besætninger svarende til en årlig risiko for besætningssmitte på 0.52 . Den årlige risiko for smitte af et enkelt dyr var 0.31. Serologisk undersøgelse af få yngre dyr samt bestemmelse af antistoftiteren på tankmælk gav god evidens for igangværende smitte i besætningen.

Antallet af nye infektioner $\mathrm{i}$ besætningerne var højere end hvad der ville være sandsynligt, hvis introduktionerne udelukkende skulle være sket ved indkøb af persistent inficerede dyr.

(Received July 9, 1992; accepted December 18, 1992).

Reprints may be requested from: H. Houe, Department of Clinical Studies, Royal Veterinary and Agricultural University, Bülowsvej 13, DK-1870 Frederiksberg C, Denmark. 